\title{
Molecular characterization of 'Candidatus Liberibacter' species/strains causing huanglongbing disease of citrus in Kenya
}

\author{
Titus O. Magomere* \\ Plant Science and Crop Protection Department \\ University of Nairobi \\ P.O. Box 29053-00625, Nairobi, Kenya \\ Tel: 25402631314 \\ Fax: 254020632121 \\ E-mail: magomeretito@gmail.com
}

\section{Silas D. Obukosia}

Plant Science and Crop Protection Department University of Nairobi

P.O. Box 29053-00625, Nairobi, Kenya

Tel: 25402631314

Fax: 254020632121

\section{Eunice Mutitu}

Plant Science and Crop Protection Department University of Nairobi

P.O. Box 29053-00625, Nairobi, Kenya

Tel: 25402631314

Fax: 254020632121

Christopher Ngichabe

Kenya Agricultural Research Institute

P. O. Box 57811, Nairobi, 00200 Kenya Tel: 25402631314

Fax: 254020632121

Florence Olubayo

Plant Science and Crop Protection Department University of Nairobi

P.O. Box 29053-00625, Nairobi, Kenya

Tel: 25402631314

Fax: 254020632121

\section{Solomon Shibairo}

Plant Science and Crop Protection Department University of Nairobi

P.O. Box 29053-00625, Nairobi, Kenya

Tel: 25402631314

Fax: 254020632121

Financial support: Rockefeller Foundation (Forum).

Keywords: citrus greening disease, DNA sequencing, intergenic regions, phylogeny, ribosomal protein genes.

Abbreviations: HLB: huanglongbing

LH: lower highlands

LM: lower midlands

MA: monoclonal antibodies

UM: upper mislands

This study was undertaken to characterize the alpha subgroup of the proteobacteria causing the huanglongbing (HLB) disease of citrus from three different ecological zones of Kenya namely the Lower highlands (LH2, LH3, 1800-1900 $\mathrm{m}$ above sea level);
Upper midlands (UM3, UM4, 1390-1475m), Lower midlands (LM5, LM4, LM3 of 1290-1340-1390m), by isolation and sequencing DNA encoding the L10 and L12 ribosomal proteins and the intergenic region. A 7I6-basepair DNA fragment was amplified and

*Corresponding author 
sequenced and consisted of 536 basepairs of DNA encoding the L10 protein, 44 basepairs of DNA intergenic region and 136 basepairs of DNA that partially encodes the $\mathbf{L 1 2}$ protein. Sequences of rpL10/L12 protein genes from Kenyan strains were 98\% and $81 \%$ similar to the South African 'Candidatus Liberibacter africanus strain Nelspruit' and the Asian 'Candidatus Liberibacter asiaticus' strains, respectively. The intergenic rDNA sequence of Kenyan strain from UM and LM showed $84 \%$ similarity with 'Candidatus $\mathrm{L}$. africanus strain Nelspruit' and $50 \%$ similarity with 'Candidatus L. asiaticus' strain. However, the LH strain had an 11- basepairs deletion, while the LM4 had a 5basepair deletion in the intergenic region compared to 'Candidatus L. africanus strain Nelspruit'. The L10 amino acid sequence was $100 \%$ homologous among HLB bacteria obtained from the agro-ecological zones in Kenya and the L10 protein sequence was also homologus to 'Candidatus L. africanus strain Nelspruit'. Nevertheless, the L10 amino acid sequence of 'Candidatus $L$. asiaticus' and the 'Candidatus $L$. africanus subsp. capensis' differed from the Kenyan strains by $18.36 \%$ and $11.82 \%$, respectively. Phylogenetic analysis of both the L10/L12 rDNA sequences and the $\mathrm{L10}$ amino acid sequences clustered the Kenyan strains of the 'Candidatus Liberibacter' species with members of alpha subdivision of proteobacteria.

Huanglongbing (HLB) disease of citrus, also called the citrus greening disease was first reported in China in 1919 and in Africa in 1929. It is a severe and widespread disease of citrus in Asia, south-east Asia, south and eastern Africa, the Arabian peninsular (Garnier and Bové, 1993) and the Americas (Coletta-Filho et al. 2005; Teixeira et al. 2005a). In Africa it has been reported in Ethiopia, Kenya, Malagasy, Sudan, Swaziland, Tanzania and Zimbabwe (Bové, 2006). HLB disease is caused by an uncultured obligate, rod shaped, gram-negative phloem restricted bacterium that has recently been characterised (Jagoueix et al. 1994). The 'Candidatus' generic name Liberibacter as defined by Murray and Schleifer (1994), for uncultured organisms has been given to the bacterium. The Liberibacters from Asia and Africa belong to two different 'Candidatus' species, namely Liberibacter asiaticus and Liberibacter africanus (Villechanoux et al. 1993; Jagoueix et al. 1994; Planet et al. 1995; Hung et al. 2004). Recently, a third species 'Candidatus Liberibacter americanus' was identified in Brazil (Coletta-Filho et al. 2005; Teixeira et al. 2005a; Teixeira et al. 2005b; Teixeira et al. 2005c).

HLB disease is transmitted among citrus trees by two psyllid vectors, Trioza erytrae (Del Guercio) in Africa and Diaphorina citri (Kuwayawa) in Asia (French et al. 2001; Boykin et al. 2007; Grafton-Cardwell et al. 2007). In Asia the proteobacteria causing HLB disease seem to be heattolerant as symptoms occur even at temperatures well above $30^{\circ} \mathrm{C}$. In Africa, the disease is prevalent only in cold areas where temperatures do not exceed $30^{\circ} \mathrm{C}$. The proteobacteria is thought to be heat-sensitive (Bové et al. 1974). For many years the distinction between the heattolerant and the heat-sensitive has been the only indication that two different strains of bacterium occurred, until Garnier et al. (1987), developed MA against "Fuzhou" strain from China and "Nelspruit" strain from South Africa. MAs against proteobacteria are highly specific and only react with the homologous MA serotypes of bacteria; however, the MAs are too specific for detection of all or most strains of the proteobacteria (Villechanoux et al. 1992).

Villechanoux et al. (1992) first reported the use of DNA probes to detect Asia HLB causing bacterium strains. Hocquellet et al. (1997) developed radioactive probes and later non-radioactive probes for distinguishing between the Africa and Asiatic bacterium strains. Planet et al. (1995) cloned and sequenced the rplKAL-rpoBc operon of the African proteobacteria, which was used for characterization of the African strain of HLB causing bacterium. Teixeira et al. (2008) sequenced the $\beta$ operon of the American liberibacter, and compared it with that of the African and Asian liberibacters. Other molecular studies on the proteobacteria have involved PCR detection based on the 16S ribosomal operon followed by digestion of the PCR products to distinguish between the African and Asiatic strain. Later an improvement on this protocol involved PCR-based detection of the ribosomal protein genes of the $\beta$ operon without concomitant enzymatic digestion (Hocquellet et al. 1999a; Hocquellet et al. 1999b; Fang et al. 2004; Lan et al. 2004; Okuda et al. 2005; Li et al. 2007; Li et al. 2008; Tatineni et al. 2008). Bastianel et al. (2005) described an omp-based PCR-RFLP analysis method for detecting and differentiating 'Candidatus Liberibacter asiaticus' isolates. Jagoueix et al. (1997) cloned and sequenced the intergenic spacer region 16S/23S rDNA of two strains of 'Candidatus L. asiaticus' (Fuzhou from China), Poona from India and one strain Nelspruit from South Africa belonging to 'Candidatus L. africanus'. These three strains from the two species belong to different serotypes and had $79.46 \%$ similarity in DNA of the intergenic spacers. The Asian strains were further characterized at the $16 \mathrm{~S}$ and $16 \mathrm{~S} / 23 \mathrm{~S}$ rDNA showing $85.5 \%$ to $100 \%$ similarity (Subandiyah et al. 2000; Fusayasu et al. 2006; Urasaki et al. 2007; Urasaki et al. 2008).

It is difficult to get accurate assessments of yield losses from HLB disease in a perennial crop such as Citrus. However, infected branches produce little or no marketable fruit. Experiments in South Africa and reunion to rejuvenate HLB infected Citrus, using tetracycline injection, have reported increases in yields of up to $140 \%$. In Kenya, yield losses of $100 \%$ have been reported and it is speculated that HLB disease causing proteobacteria in Kenya emanated from introduction of infected scions imported from South Africa since most citrus propagules were obtained from South Africa and to a limited extent from Israel. HLB disease was first diagnosed in Kenya 


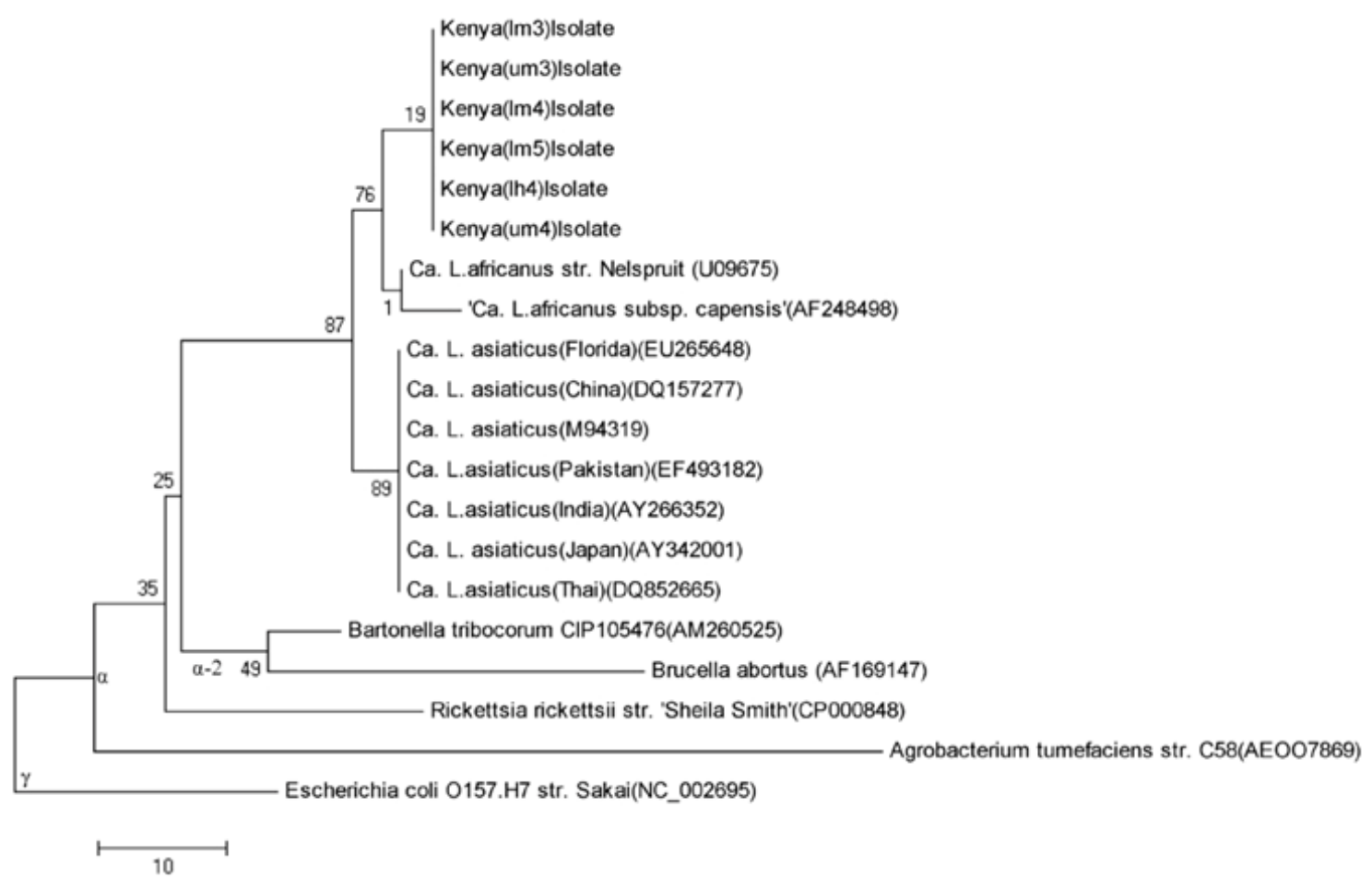

Figure 1. Minimum- evolution phylogenetic tree constructed from alignment of L10/L12 rDNA of 'Candidatus Liberibacter' species (accession numbers in parenthesis) and other $\alpha$ Proteobacteria. The phylogenetic history was inferred using the NeighborJoining method. Bootstrap values are shown at the nodes. Phylogenetic analyses were conducted in MEGA4.

using electron microscopy in 1982 and the disease led to the subsequent destruction of all sources of propagules from National Nurseries located in the highland areas. Although HLB disease has been in Kenya for the last 20 years, there is no information of what species/strain of the proteobacteria present. 'Candidatus L. africanus' has been thought to be the cause of the disease based on the assumption that HLB disease in Kenya originated from South Africa. In a recent study (unpublished) we adopted the PCR diagnostic procedures developed by Hocquellet et al. (1999) to HLB samples from Kenya collected at different altitudes. In this study we report on DNA sequencing of the L10/L12 ribosomal protein genes and their intergenic region in HLB disease causing proteobacteria samples collected from infected citrus at different altitudes from three agro-ecological zones and define phylogenetic relationships among the proteobacteria.

\section{MATERIALS AND METHODS}

\section{DNA extraction and partial purification}

Leaf midribs ( 0.1 to $0.3 \mathrm{~g}$ ) were chopped to a fine mince with a razor blade in a disposable petri-dish in extraction buffer containing $1 \mathrm{~mL}$ of TE buffer $(10 \mathrm{mM}$ Tris $\mathrm{pH}$ 8.0, $400 \mathrm{mM}$ EDTA plus 1\% SDS and $0.25 \mathrm{mg}$ of proteinase $\mathrm{K}$ ) (Jagoueix et al. 1996). The homogenate was transferred to an eppendorf tube and incubated for 2 hrs at $65^{\circ} \mathrm{C}$. The suspension was centrifuged for $15 \mathrm{~min}$ at $12,000 \mathrm{x}$ g and the supernatant mixed with $1 \mathrm{~mL}$ of Wizard Min Prep DNA purification resin (Promega). The resin was transferred to a mini-column and washed twice with $2 \mathrm{~mL}$ of $80 \%$ isopropanol. Thereafter, $50 \mu \mathrm{L}$ of hot water $\left(80^{\circ} \mathrm{C}\right)$ was added, incubated for $1 \mathrm{~min}$ and centrifuged at $16,000 \mathrm{x} \mathrm{g}$ for $30 \mathrm{sec}$ in an eppendorf tube. This step was repeated to have a total yield of $100 \mu \mathrm{L}$ of extract. The extract was stored at $-20^{\circ} \mathrm{C}$.

\section{Amplification of the L10/L12 ribosomal protein rDNA}

Two primers were used to amplify the intergenic region of ribosomal protein L10/L12 rDNA and the L10 rDNA of the bacterium. Forward primer 5' (CATCGGGAGATGAAAGTTGAATA) and reverse primer 5' (TTCCCCTGCCGCAGACGCAACA). Amplification was done by PCR (Hybrid OMN-E Thermal Cycler) with the reaction conditions by Jagoueix et al. (1996). The PCR reaction was performed in $50 \mu \mathrm{L}$ of reaction mixture containing $1 \mu \mathrm{m}$ of each of the primers, Gibco buffer, $200 \mu \mathrm{M}$ of each of the four dNTP, $2 \mathrm{mM}$ $\mathrm{MgCl}_{2}, 0.05 \% \mathrm{~W} 1$ detergent (Gibco BRL), $100 \mu \mathrm{g} / \mathrm{mL}$ BSA and $2.5 \mathrm{U}$ of Taq polymerase (Gibco BRL). The reaction mix was amplified for 35 cycles with the thermal cycler at: $92^{\circ} \mathrm{C}$ for $20 \mathrm{sec}$ (denaturation of template into single strand); $62^{\circ} \mathrm{C}$ for $20 \mathrm{sec}$ (annealing of primers to each original strand, high temperatures are used due to the 


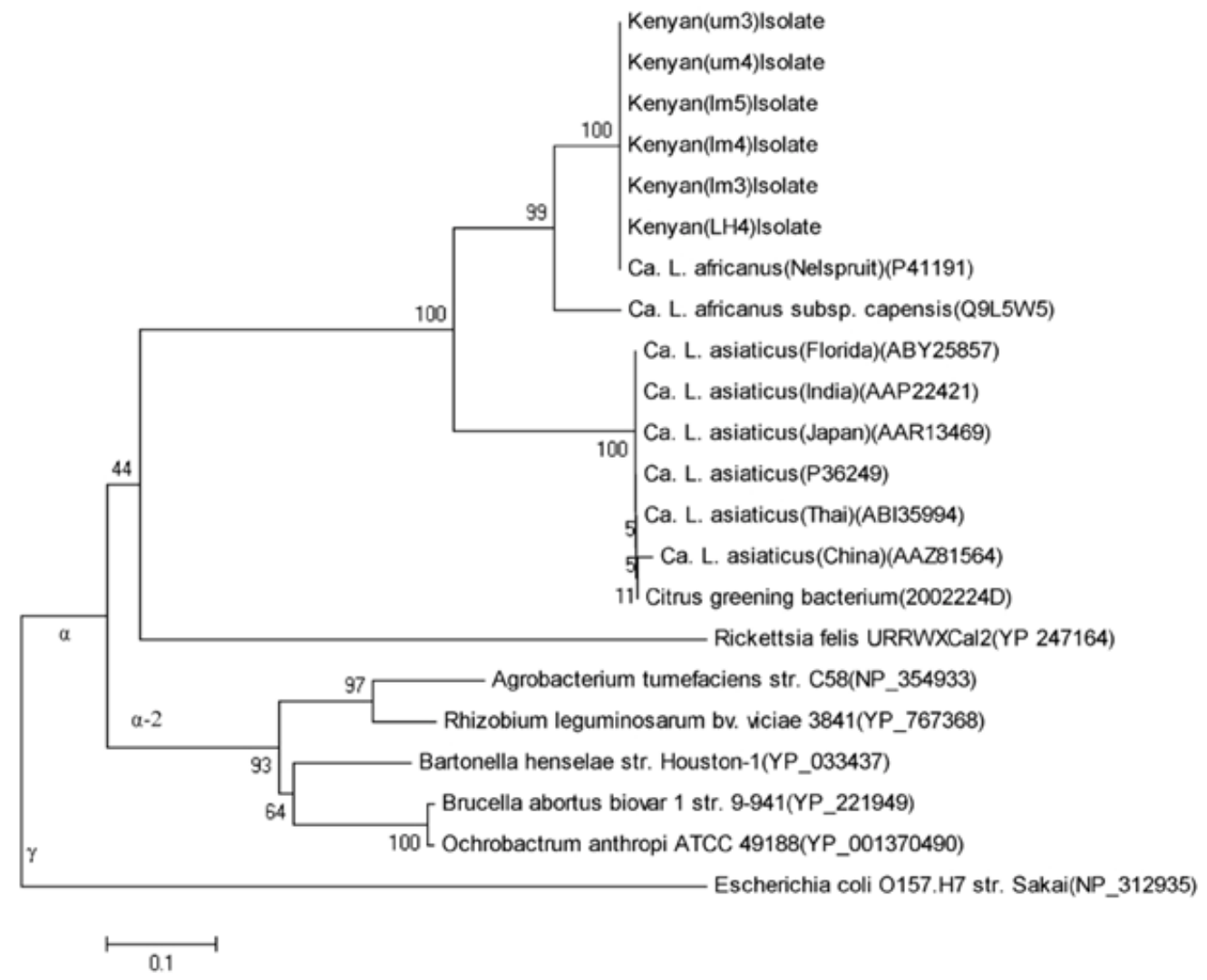

Figure 2. Minimum-evolution phylogenetic tree constructed from alignment of translated ribosomal protein L10 of 'Candidatus Liberibacter' species (accession numbers in parenthesis) and other aProteobacteria. The phylogenetic history was inferred using the Neighbor-Joining method. The evolutionary distances were computed using the Maximum Composite Likelihood method. Phylogenetic analyses were conducted in MEGA4. Bootstrap values are shown at the nodes.

specificity of the primers); and $72^{\circ} \mathrm{C}$ for 45 sec (elongation and new strand synthesis). PCR products were analyzed by electrophoresis of $20 \mu \mathrm{L}$ of each sample (Jagoueix et al. 1996).

\section{Agarose gel electrophoresis and DNA elution from the gel}

PCR products were electrophoresed on $1 \%$ agarose gels and Tris-borate buffer ( $1 \mathrm{X}$ TBE) and stained in ethidium bromide at $0.5 \mu \mathrm{g} / \mathrm{mL}$. $20 \mu \mathrm{L}$ of the PCR products were mixed with $1 \mu \mathrm{L}$ of gel loading dye and loaded into gel. The gel was run at a voltage of $4 \mathrm{~V} / \mathrm{cm}$. After electrophoresis and photography, the DNA was extracted from the gel by use of a Gel Extraction Kit (Life Technologies). A gel slice containing the DNA was cut with a sharp razor under UV Light. The gel slice was weighed and $400 \mathrm{mg}$ of the $1 \%$ gel was placed into a 1.5 $\mathrm{mL}$ propylene tube. Thereafter, $1.2 \mathrm{~mL}$ of gel solubilization buffer (concentrated sodium percholate, sodium acetate, and TBE solubilizer) was added. This was incubated at $50^{\circ} \mathrm{C}$ for $15 \mathrm{~min}$, during which the solution was mixed every $3 \mathrm{~min}$ to ensure gel dissolution. The DNA was recovered through a cartridge based protocol (Life Technologies).

\section{DNA sequencing}

Automated fluorescent DNA sequencing/Sanger-Dideoxy Nucleoside Triphosphate Chain Termination DNA Sequencing method was used. Big Dye chemistry with ABI PRISM $^{\circledR}$ BigDye $^{\mathrm{TM}}$ Terminators v 3.0 and AmpliTaq ${ }^{\circledR}$ DNA polymerase Dyes attached to the four dideoxynucleotide terminators were used for sequencing. The cycling reaction was done on a GeneAmp ${ }^{\circledR}$ PCR System with a MicroAmp ${ }^{\circledR}$ 96-Well Reaction Plate. The PCR fragments obtained were then separated on a denaturing polyacrylamide gel on Perkin Elmer ABI PRISM ${ }^{\circledR} 377$ DNA sequencer. The dyes were detected by fluorescence after excitation. The sequence information was decoded by a 3100-Avant Genetic Analyzer soft ware. The PCR product was sequenced directly without cloning it in vectors.

\section{Purification of sequencing template}

This procedure was performed to remove primers and dNTPs, A G-50 w/spin column was rinsed by adding 300 $\mu \mathrm{L} \mathrm{H}_{2} \mathrm{O}$ to spin column and span in a microfuge. $600 \mu \mathrm{L}$ Sephadex G-50 slurry ( $1 \mathrm{~g} / 15 \mathrm{~mL}$ in $\left.\mathrm{ddH}_{2} 0\right)$ was added to the spin column and microfuge at 4900 RPM for 60 sec. 20 


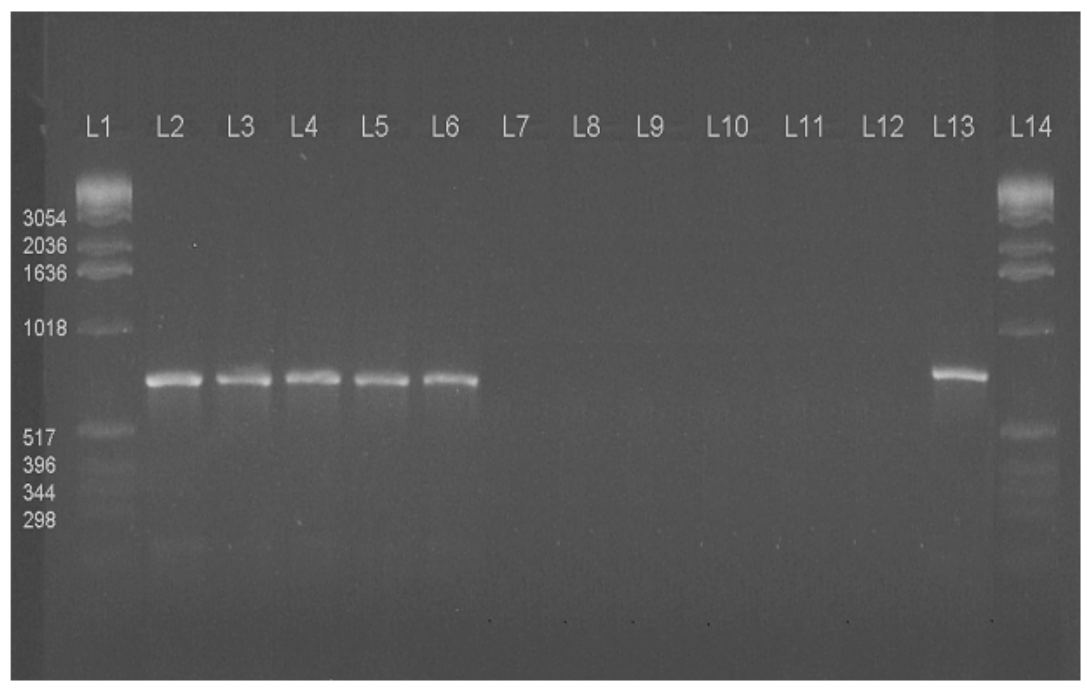

Figure 3. 1\% agarose electrophoresis gel of L10/L12 ribosomal protein PCR products. Lanes 7 -11-undiseased; lanes 2-6 positive 716bp amplification from infected samples; lanes 1 and 14 1kb DNA ladder; lane 12 negative control; lane 13 positive control. The results show that plants from tissue culture supported nurseries were HLB-disease free, while plants from low altitude nurseries/fields (1000 $\mathrm{m}$ above sea level) and high altitude $(2000 \mathrm{~m})$ not supported by tissue culture were infected with the 'Candidatus Liberibacter africanus' giving a PCR fragment of 716 base pairs.

$\mu \mathrm{L}$ PCR products was loaded to the center of the Sephadex and microfuged at $4900 \mathrm{RPM}$ for $60 \mathrm{sec}$ and the product was transferred into fresh $1.5 \mathrm{~mL}$ eppendorf tube (QIAGEN Guide, 1998; Applied Biosystems, 2002).

\section{Extension/termination reactions}

A reaction mixture consisting of template DNA 30-90 ng, primer $2.0-3.0 \mathrm{pmol}$, buffer $4.0 \mu \mathrm{L}, \mathrm{T}$ and terminator Ready Reaction mix $2.0 \mu \mathrm{L}$ was added into a $500 \mu \mathrm{L}$ eppendorf tube and made to final volume of $20 \mu \mathrm{L}$ with sterile $\mathrm{H}_{2} \mathrm{O}$ (Perkin-Elmer Corporation, 1997; Applied Biosystems, 2002). The reaction mixture was briefly mixed by pipetting. It was overlaid with 2 drops of mineral oil and spun down. The reaction tubes were placed into a thermalcycler (ThermoHybaid Omni-E) that had been preheated to $95^{\circ} \mathrm{C}$ in a start the cycling program. The preheating was to prevent non-specifically annealed primers from being extended (and thus stabilized) by Amplitaq DNA polymerase. Thermalcycler was programmed to run at $95^{\circ} \mathrm{C}$ for $1 \mathrm{~min} 30 \mathrm{sec}$ preheating, then $95^{\circ} \mathrm{C}$ for $30 \mathrm{sec}, 59^{\circ} \mathrm{C}$ for $15 \mathrm{sec}$ (sequence-specific annealing temperature), $60^{\circ} \mathrm{C}$ for $4 \mathrm{~min}$ and 25 cycles. The sample was stored at $4^{\circ} \mathrm{C}$ at the end of the cycles. The PCR products were purified by running the products through Centri-Sep Columns to remove excess dye terminators (Perkin-Elmer Corporation, 1997; Applied Biosystems, 2002). $1.5 \mu \mathrm{L}$ of the purified PCR products were loaded on 5.0\% Long Ranger, 6 M-urea gel.

\section{DNA sequencing and homology comparisons}

The DNA was sequenced in a $48 \mathrm{~cm}$ ABI sequencing gel (5.0\% long ranger acrylamide, $6 \mathrm{~m}$ urea). The gel consisted of 18.0 g urea, $5.0 \mathrm{~mL} 10 \mathrm{X}$ TBE, $5.0 \mathrm{~mL}$ Long Ranger,

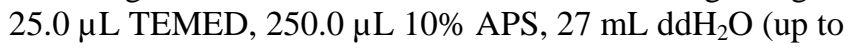

50 mL) (Perkin-Elmer Corporation, 1997; Applied Biosystems, 2002). After polymerization for 10-15 min the gel was positioned and warmed for $15 \mathrm{~min}$ to $51^{\circ} \mathrm{C}$. Samples were heated to $95^{\circ} \mathrm{C}$ for $2 \mathrm{~min}$ and cooled on ice and $1.5 \mu \mathrm{L}$ loaded in each well. Buffer was loaded into any empty wells to the right and left of the samples. The gel was run at a constant 48 watt for 8 hrs and the ABI basecaller results were received in ASCII format and were subjected to homology comparisons with other published sequences in the GenBank, EMBL, DDBJ, PDB Database using the BLAST (basic logical alignment sequencing tool) (Altschul et al. 1997), on the National Center for biotechnology information (NCBI) Genbank website.

\section{Phylogeny analysis for the L10/L12 rDNA}

Bootstrap test of phylogeny using the neighbourhood joining method and molecular evolutionary analyses were conducted using MEGA version 4 (Tamura et al. 2007). The L10/L12 rDNA sequences and the L10/L12 intergenic regions of 'Candidatus Liberibacter' species from different agro-ecological zones in Kenya and those reported on the National Centre for Biotechnology Information (NCBI) Genbank were used in the analysis. The evolutionary distances were computed using the Maximum Composite Likelihood method (Tamura et al. 2004) and are in the units of the number of base substitutions per site. All positions containing gaps and missing data were eliminated from the dataset (Complete deletion option). There were a total of 99 positions in the final dataset. Seven L10 rDNA, L10/L12 intergenic rDNA and partial L12rDNA sequences from 'Candidatus Liberibacter asiaticus' species were utilized in the analysis, they included isolate "Thai" (accession no. DQ852665), isolate "Japan” (accession no. AY342001), isolate "India" (accession no. AY266352), isolate 
Table 1 Composition of medium in transformation experiment.

\begin{tabular}{|l|c|c|c|c|c|c|c|c|}
\hline \multicolumn{1}{|c|}{$\begin{array}{c}\text { Homology } \\
\text { Gene }\end{array}$} & LM4/UM3 & LM4/UM4 & LM4/LH4 & LM4/LM5 & LM4/LM3 & LM4/LAN & LM4/CLA & LM4/LAC \\
\hline $\begin{array}{l}\text { RPL1O/RPL12 intergenic } \\
\text { gene }\end{array}$ & 100 & 100 & 84.09 & 100 & 100 & 83.67 & 49 & 65.31 \\
\hline $\begin{array}{l}\text { RPL10 } \\
\text { gene }\end{array}$ & 100 & 100 & 100 & 100 & 100 & 99 & 83 & 83.18 \\
\hline $\begin{array}{l}\text { RPL12 } \\
\text { partial gene }\end{array}$ & 100 & 100 & 100 & 100 & 100 & 99.26 & 91.9 & 84.56 \\
\hline L10 amino acid sequence & 100 & 100 & 100 & 100 & 100 & 100 & 81.64 & 88.18 \\
\hline RPL10/RPL12 DNA (720BP) & 100 & 100 & 94.7 & 100 & 100 & 98 & 81 & 83 \\
\hline
\end{tabular}

"Pakistan" (accession no. EF493182), isolate "Asia” (accession no. M94319), isolate "China” (accession no. DQ157277), and isolate "Florida" from the USA (accession no. EU265648). Two sequences were from South Africa 'Candidatus Liberibacter africanus subsp. capensis' (accession no. AF248498) and 'Candidatus Liberibacter africanus str. Nelspruit' (accession no. U09675). Other Proteobacteria belonging to the $\alpha$ subdivision used included, Agrobacterium tumefaciens str. C58 (accession no. AEOO7869), Rickettsia rickettsii str. 'Sheila Smith' (accession no. CP000848), Brucella abortus (accession no. AF169147), and Bartonella tribocorum CIP105476 (accession no. AM260525). Escherichia coli O157.H7 str. Sakai (accession no. NC_002695) was used as an outgroup and belongs to the $\gamma$ subdivision of Proteobacteria. Six isolates from Kenya (Kenya (lm3) isolate, Kenya (um3) isolate, Kenya ( $\operatorname{lm} 4)$ isolate, Kenya ( $\operatorname{lm} 5)$ isolate, Kenya (lh4) isolate and Kenya (um4) isolate were utilized in the analysis (Figure 1).

\section{Phylogeny analysis for the ribosomal protein L10}

The amino acid sequence of the L10 protein of 'Candidatus Liberibacter' species from Kenya and those reported were also used in determining phylogeny within the species. The phylogenetic history was inferred using the Minimum Evolution method with a bootstrap test (500 replicates). The evolutionary distances were computed using the Poisson correction method and the ME tree was searched using the Close-Neighbor-Interchange (CNI) algorithm (Nei and Kumar, 2000). The Neighbor-joining algorithm was used to generate the initial tree in MEGA4 (Tamura et al. 2007). Six L10 protein amino acid sequences from Kenyan isolates (Kenya ( $\operatorname{lm} 3$ ) isolate, Kenya (um3) isolate, Kenya (lm4) isolate, Kenya (lm5) isolate, Kenya (lh4) isolate and Kenya (um4) isolate) were utilized in the analysis with L10 proteins from South African isolates 'Candidatus Liberibacter africanus subsp. capensis' (accession no. Q9L5W5) and 'Candidatus Liberibacter africanus str. Nelspruit' (accession no. P41191). The 'Candidatus Liberibacter asiaticus' isolates included isolate “Thai" (accession no. ABI35994), isolate “Japan” (accession no. AAR13469), isolate "India” (accession no. AAP22421), isolate “Asia” (accession no. P36249), isolate "China” (accession no. AAZ81564) and isolate "Florida" from the USA (accession no. ABY25857). Other Proteobacteria belonging to the $\alpha$ subdivision used included, Agrobacterium tumefaciens str. C58 (accession no. NP_354933), Rhizobium leguminosarum bv. viciae 3841 (accession no. YP_767368), Bartonella henselae str. Houston-1(accession no. YP_033437), Brucella abortus biovar 1 str. 9-941 (accession no.YP_221949), Ochrobactrum anthropi ATCC 49188 (accession no.YP_001370490). Escherichia coli O157.H7 str. Sakai (accession no. NP_312935) was used as an outgroup and belongs to the $\gamma$ subdivision of Proteobacteria (Figure 2).

\section{RESULTS AND DISCUSSION}

\section{DNA sequences of L10 and L12 ribosomal protein genes}

A 7I6-basepair DNA fragment was amplified (Figure 3) and sequenced, producing 536 basepairs of DNA encoding the L10 protein, 44 basepairs of DNA intergenic region and 136 basepairs of DNA that partially encodes the L12 protein. Genes encoding the L10 protein of alpha subgroup proteobacteria have been sequenced and characterized in 'Candidatus L. africanus strain Nelspruit' from South Africa (Planet et al. 1995), 'Candidatus L. africanus subsp. capensis' (Garnier et al. 2000) in 'Candidatus L. asiaticus' (Asiatic strains) (Villechanoux et al. 1993; Okuda et al. 2005) and in 'Candidatus L. americanus' (Teixeira et al. 2008). The L10 and L12 protein are transcribed from the rplKAJL-rpoBC ribosomal protein-RNA polymerase gene cluster. The most abundant transcript is the 2600 nucleotide tetracistronic L11-L1-L10-L12 mRNA initiated at the upstream major PL11 promoter and terminated at the 
transcription attenuator in the L12-beta intergenic space (Petterson, 1979). Comparison DNA sequence of the rpL10 protein gene showed that the Kenyan isolates from different agro-ecological zones were $100 \%$ homologous to one another. In contrast the rpL10 DNA sequence from the Kenyan strains was $99 \%, 83 \%$ and $83.18 \%$ similar to 'Candidatus L. africanus strain Nelspruit', 'Candidatus L. africanus subspecies capensis' and 'Candidatus L. asiaticus' strains, respectively (Table 1). Comparisons of the partial 136 base sequence of the rpL12 gene showed $100 \%$ homology among isolates from the Kenya's agro-ecological zones, but $99.26 \%, 91.9 \%$ and $84.56 \%$ similarity to the 'Candidatus L. africanus strain Nelspruit', 'Candidatus L. asiaticus' and 'Candidatus L. africanus subsp. capensis' strains, respectively (Table 1). The low similarity between the Kenyan isolates and 'Candidatus L. africanus subsp. capensis' as compared to 'Candidatus L. asiaticus' may be attributed to the incomplete sequence of the $r p L 12$ gene. However, the Kenyan strains of the alpha subgroup of HLB disease causing proteobacteria were different from the strains characterized from South African strains and the Asiatic strains, but more closely related to the former than the later based on the $r p L 10$ and the $r p L 12$ protein gene.

\section{Translation and comparison of L10 ribosomal protein}

In the current study, DNA sequence of L10 gene was translated into a 169 amino acid protein sequence, with a molecular weight of 18637.6 and an atomic formula: $\mathrm{C}_{829} \mathrm{H}_{1388} \mathrm{~N}_{232} \mathrm{O}_{248} \mathrm{~S}_{2}$. It had an estimated half-life of 30 hrs and an instability index of 32.85, which classifies the protein as stable. It had a start codon of TTG at the seventeenth base while the L12 protein has its start codon at the $580^{\text {th }}$ base in Kenyan isolate LM4 (Figure 4). In prokaryotes the ribosomal protein L10 is one of the proteins from the large ribosomal subunit that belongs to the L10 protein family of ribosomal proteins. L10 proteins range in size from 135 amino acids in proteobacteria Brucella abortus (Oliveira et al. 1994) to 199 amino acids in both aquificae Aquifex aeolicus (Deckert et al. 1998) and A. pyrophilus (Klent et al. 1999) and they have only been found so far in eubacteria. The ribosomal protein L8 is a
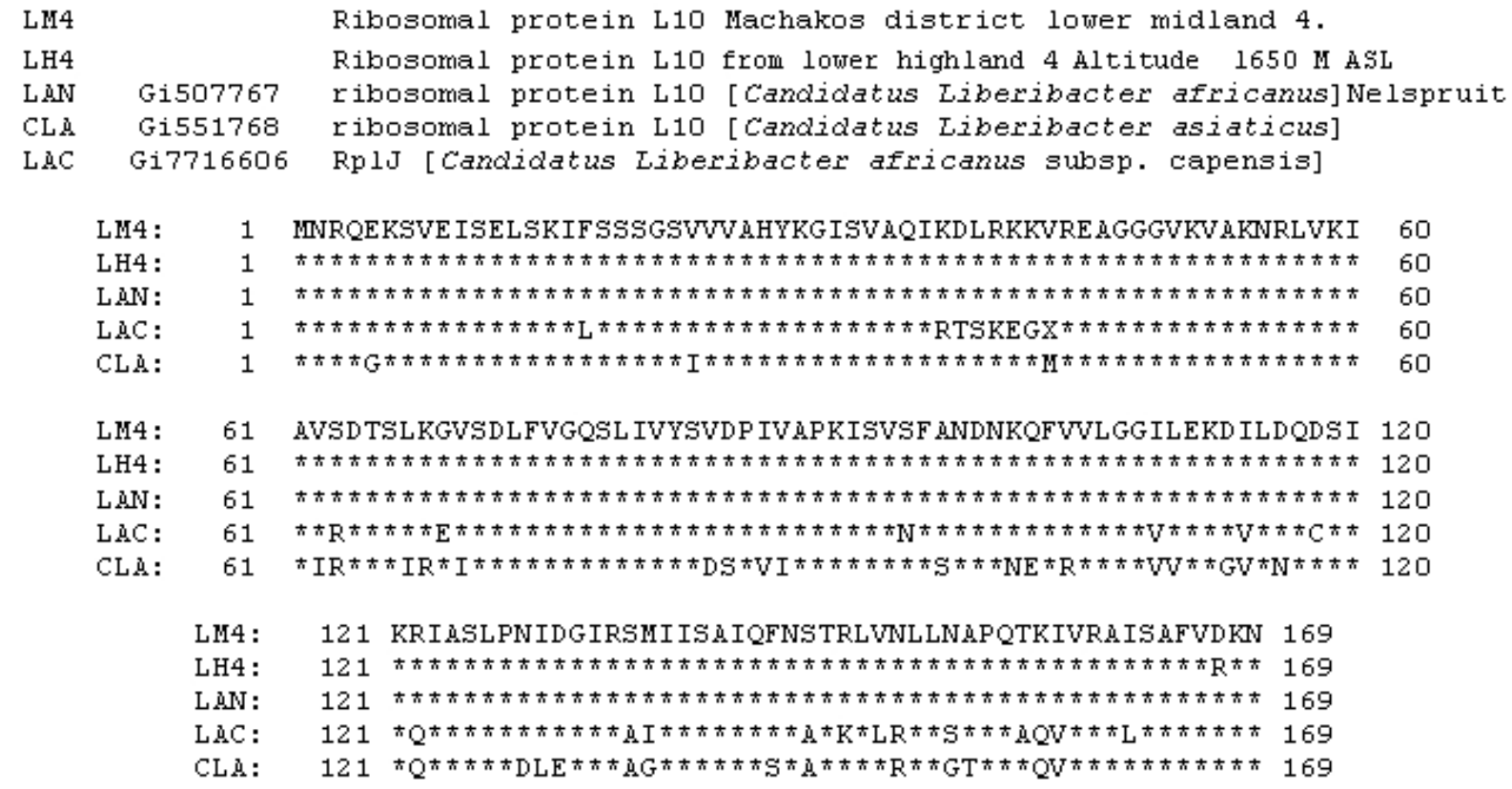

The composition of amino acids in the L10 protein is as follows

$\begin{array}{ll}\text { Ala (A) } 127.0 \% ; & \text { Lys (K) } 169 \\ \text { Arg (R) } 84.7 \% ; & \text { Met (M) } 21.2 \% ; \\ \text { Asn (N) 9 5.2\%; } & \text { Phe (F) } 63.5 \% ; \\ \text { Asp (D) } 105.8 \% ; & \text { Pro (P) } 42.3 \% \\ \text { Cys (C) } 0.0 \% ; & \text { Ser (S) } 2212.8 \% ; \\ \text { Gln (Q) } 95.2 \% ; & \text { Thr (T) } 31.7 \% ; \\ \text { Glu (E) } 52.9 \% ; & \text { Trp (W) } 00.0 \% ; \\ \text { Gly (G) } 105.8 \% ; & \text { Tyr (Y) } 21.2 \% ; \\ \text { His (H) } 10.6 \% & \text { Val (V) } 2112.2 \% \\ \text { Ile (I) } 1911.0 \% ; & \\ \text { Leu (L) } 137.6 \% ; & \end{array}$

Figure 4. Alignment of the translated ribosomal protein L10 sequences showing amino acid variations between the Kenyan, South African and Asian strains of the bacteria. 

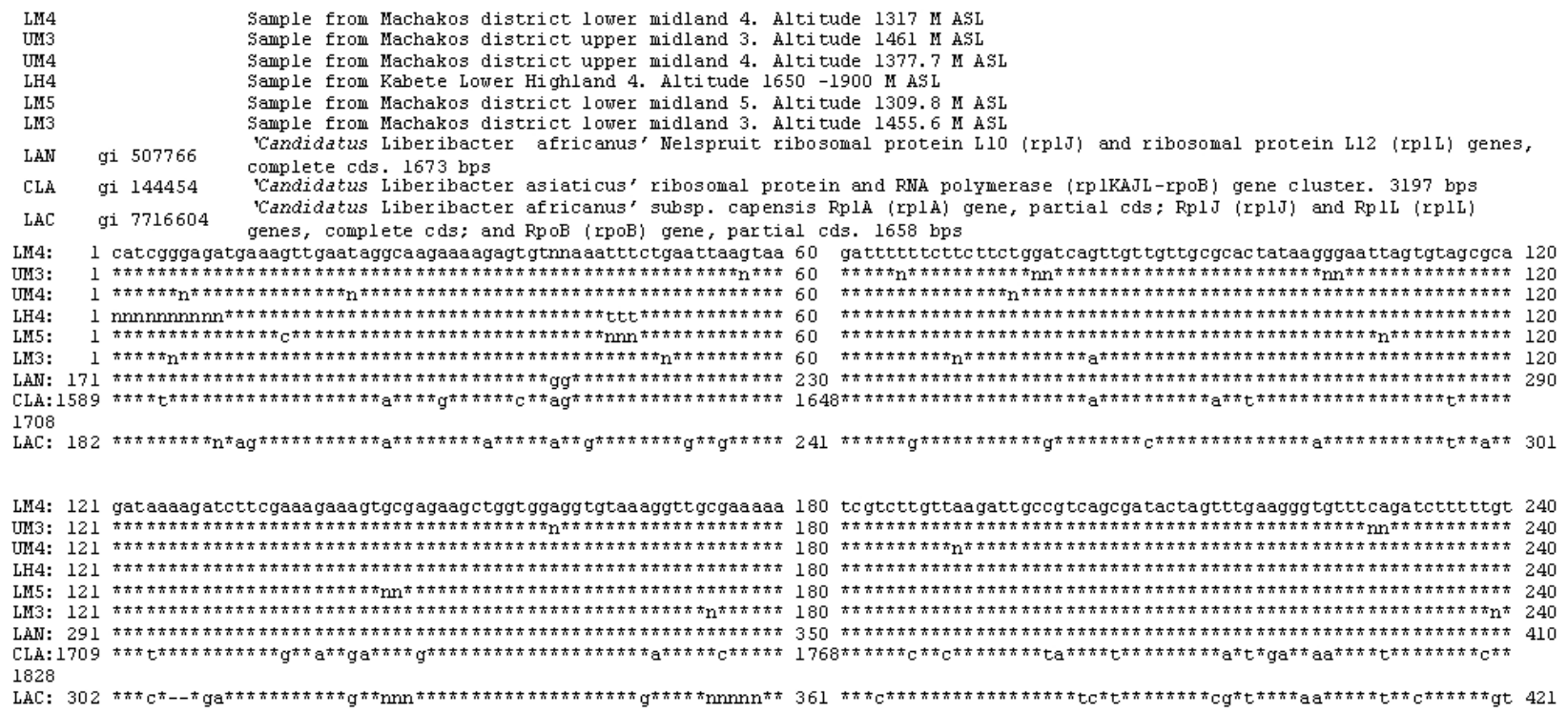

LM4: 241 tgggcaatcattgattgtttat tcggttgacc ctattgttgc tnnaagatttctgtgag 300 ctttgcgaatgataataaacagtttgtggttc ttggtggtattttggagaaagatattct 360

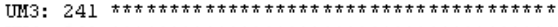

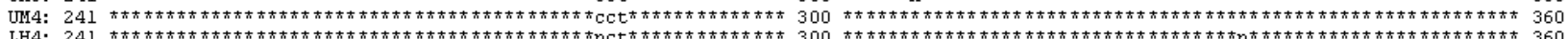
LH4: 241 HAt 360

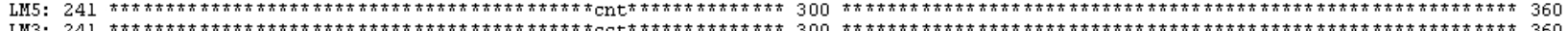

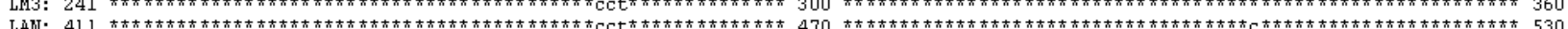

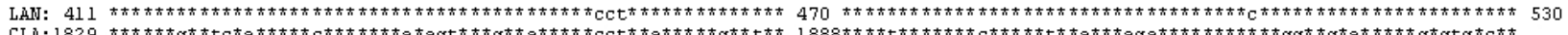

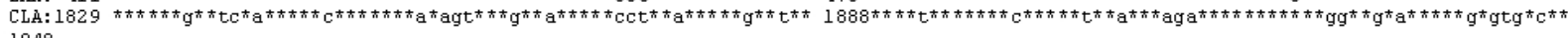
1948

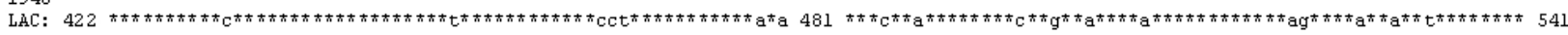

LM4: 361 tgaccaagattctatcaaacggattgcttcgttgcctaatat tgatnntattcgttctat 420 gatcattagtgc tattcaat ttaattc gactagattggtaaatcttc ttaatgcacctca 480

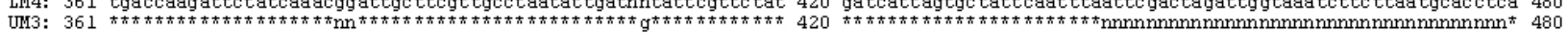

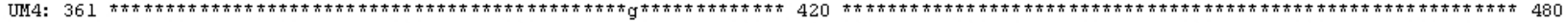

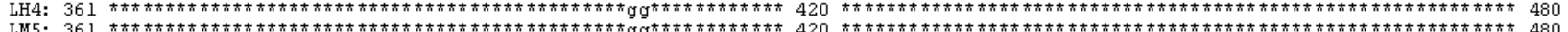

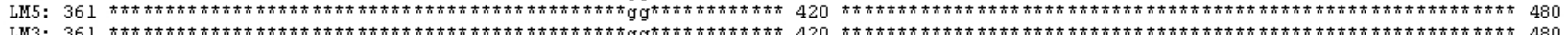

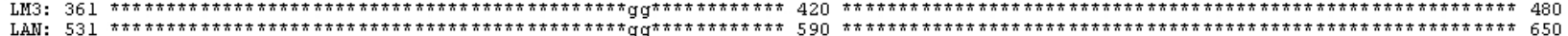

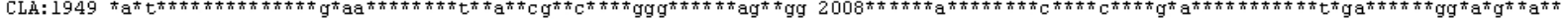
2068

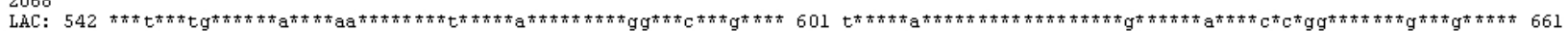

LM4: 481 gac taaaa ttgttcgtgc tatt tctgc tttg tagataaaa tcaacaaagt tagac tcc 540 aagttatt-----aataccaacaagaa taaggaaaatgtgtgatatg tccaatattgaat 595

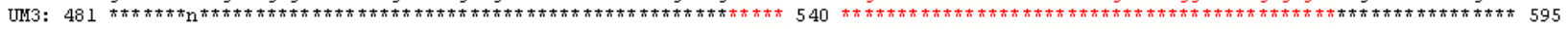

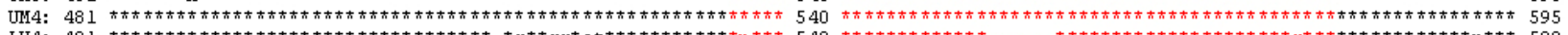

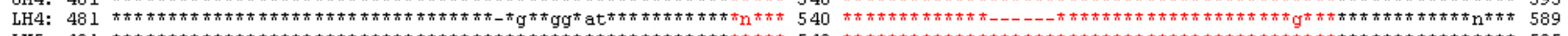

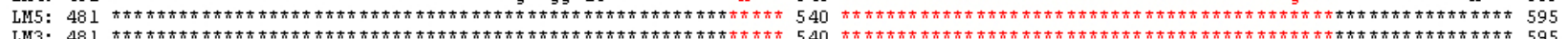

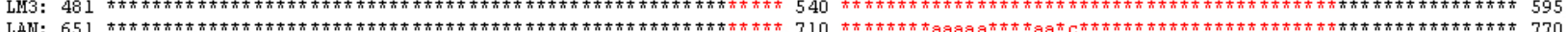

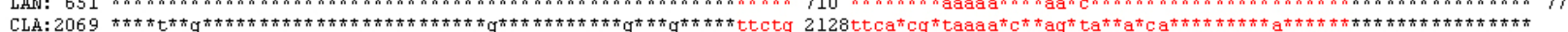
2187 (2) LAC: $662{ }^{*} \mathrm{~g}^{*} \mathrm{aC}^{* *} \mathrm{~g}^{* \pi+t}$ LM4: 596 caattgttgaaaaattatcgtc tcttacgctccttcaagcggcagaactttc taaaagat 655 tagaagaagaatggggagtttctgctgctgctcctgtagctgttgttgcgtctgctgcag 715

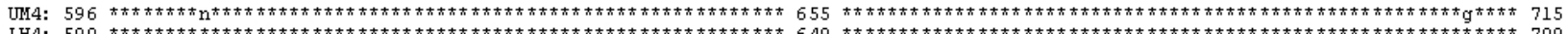
L14: 5900 596 LM5: 596 Nהतה L113: 596 t7

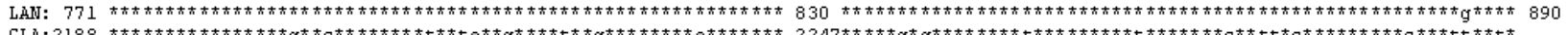

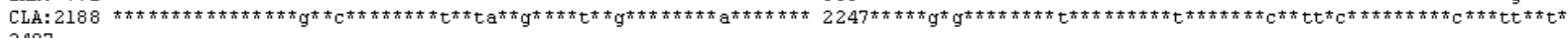
2407

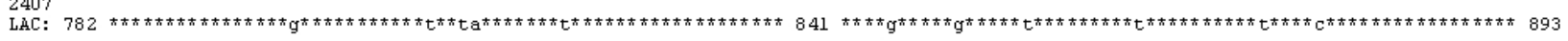

\begin{tabular}{|c|c|c|c|}
\hline LM4: & 716 & gggaa & 720 \\
\hline UM3: & 716 & 先去 & 720 \\
\hline UN4: & 716 & ネーホた & 720 \\
\hline LH4: & 710 & たネたニ た & 714 \\
\hline LM5: & 716 & ネーネニ & 720 \\
\hline LM3: & 716 & ネーネー & 720 \\
\hline LANN: & 891 & ネーネー & 895 \\
\hline CLA: & 2408 & $\mathrm{ca}^{* \pi} \mathrm{g}$ & 2413 \\
\hline LAC: & 894 & 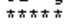 & 899 \\
\hline
\end{tabular}

Figure 5. Alignment of sequenced L10/L12 ribosomal protein DNA; ribosomal protein L10 DNA (bases 1-535), L10/ L12 intergenic DNA (bases 536-584) and L12 DNA (bases 585-720) showing nucleic acid variations between the Kenyan, South African and Asian strains of the bacteria. Showing a 5 base deletion in L10/ L12 intergenic DNA of LM4, UM3, UM4, LM5, LM3 and an eleven base deletion in $\mathrm{LH} 4$.

*signifies similarity of the base with the reference sequence, - refers to a deletion, while $\mathrm{n}$ refers to a missing base. BLAST 2 version BLASTN 2.2.6 (http://www.ncbi.nlm.nih.gov/blast/) 
complex L7/L12 and L10 (Petterson et al. 1976). The acidic stalk protein complex, L10.L7/L12 in prokaryotes, binds to a region around residues 1030-1127 in domain II of $23 \mathrm{~S}$ rRNA, termed the GTPase-associated domain (Beauclerk et al. 1984), and constitutes a partof the functional center, termed the GTPase center or factor-bindingcenter (Ban et al. 1999; Ban et al. 2000). The four copies of L7/L12 bind to L10 and form the pentameric complex (Liljas and Gudkov, 1987); the L10 moiety of the complex appears to bind directly to the rRNA domain (Petterson, 1979). In the current study, the L10 amino acid sequence of Proteobacteria isolates from LM4 and LH4 agro-ecological zones were identical to each other and to 'Candidatus L. africanus Nelspruit', but had $88.18 \%$ homology to the isolate 'Candidatus L. africanus subsp. capensis' and $81.64 \%$ similarity to 'Candidatus L. asiaticus' (Table 1). Previous comparisons of the species on the 16S/23S intergenic regions and the tRNAs ${ }^{\text {Ala }}$ sequence identified in the $16 \mathrm{~S} / 23 \mathrm{~S}$ intergenic regions of 'Candidatus L. africanus' and 'Candidatus L. asiaticus' region were found to be $79.46 \%$ and $87.8 \%$ respectively (Jagoueix et al. 1997). Furthermore, the outer membrane protein (omp) of 'Candidatus L. africanus' (isolate 'South Africa-Nelspruit') and 'Candidatus L. asiaticus' nucleotide sequences exhibited $72.2 \%$ identity, whereas the encoded polypeptides had $58 \%$ identical and $86.5 \%$ similar amino acids (Bastianel et al. 2005). Comparison of the $\beta$ operon of liberibacters shows that ' $\mathrm{Ca}$. L. africanus'and ' $\mathrm{Ca}$. L. asiaticus' shared $81.2 \%$ sequence identity, the percentage for 'Ca. L. americanus' and 'Ca.L. africanus' was only $72.2 \%$, and identity for 'Ca.L. americanus' and ' $\mathrm{Ca}$. L. asiaticus' was only $71.4 \%$ (Teixeira et al. 2008). Beyond showing variation on the L10 protein sequence in the species, these results further indicate that the Kenyan strains of the proteobacterium were more closely related to 'Candidatus L. africanus' than the 'Candidatus L. asiaticus' in the amino acid sequences of the L10 and L12 ribosomal proteins.

\section{Intergenic region of L10/L12 ribosomal protein genes}

A 44-DNA base sequence comprising of the intergenic region of 'Candidatus L. africanus' strains from Kenya was obtained from UM3, UM4, and LM5, LM3 agro-ecological zones which were five bases shorter that the sequences obtained from 'Candidatus L. asiaticus' and 'Candidatus L. africanus subsp. capensis' and 'Candidatus L. africanusstrain Nelspruit' (Figure 5). However, intergenic DNA sequences of Kenyan strain LH4 had an 11-basepair deletion compared to 'Candidatus L. asiaticus' and 'Candidatus L. africanus' strains. The intergenic regions from the LM4 isolates were $100 \%, 100 \%, 84.09 \%, 100 \%$, $100 \%, 83.67 \%, 49 \%$ and $65.31 \%$ similar to isolates from LM3, LM5, LH4, UM3, UM4, 'Candidatus L. africanus strain Nelspruit', 'Candidatus L. asiaticus' and 'Candidatus L. africanus subsp. capensis' strains, respectively (Table 1). The intergenic regions of 'Candidatus L. africanus' strain from Kenya isolated from agro-ecological zones LM3,
LM5, UM3 and UM4 were 100\% homologous to one another. Similarly, the 595 basepair intergenic region of the $16 S / 23 S$ of the 'Candidatus L. asiaticus' strains from India and the People's Republic of China were $100 \%$ homologous to one another, although they were isolated distant geographically regions (Jagoueix et al. 1997). However, the level of homology of the entire 16S/23S intergenic regions of 'Candidatus L. africanus' and 'Candidatus L. asiaticus' was $87.46 \%$ and was only 498 base pairs long (Jagoueix et al. 1997). Because of the high homology between the 'Candidatus L. asiaticus' strains from India and the People's Republic of China even though the two strains belonged two different serotypes (Jagoueix et al. 1997), concluded that probably in 'Candidatus Liberibacter' the 16S/23S intergenic region does not vary much within a species. Hence monoclonal antibodies remain the only reagents that allow identification of 'Candidatus Liberibacter' strains within a given species. However in the current study, the variability in the sequences of 'Candidatus L. africanusstrain Nelspruit' were high, 49\%, 65.31\%, and $83.67 \%$ homology respectively, to 'Candidatus L. asiaticus', 'Candidatus L. africanus subsp. capensis' and 'Candidatus L. africanus'strain from Kenya isolated from LM and UM. Results from the current study show that variability within the L10/L12 intergenic regions was high and may be used as a means of distinguishing between strains in the alpha subgroup of HLB disease causing proteobacteria. In addition the results from comparison of DNA sequences from the L10/L12 intergenic region further corroborate that the Kenyan strains of the proteobacteria are different from the South African strains and the Asiatic strains but more closely related to the former than the later.

\section{Phylogeny of the 'Candidatus Liberibacter' species}

The ribosomal DNA sequence and the intergenic rDNA sequences have been previously used to study phylogeny in Proteobacteria (Hugenholtz, 2002), among the 21 Phloemrestricted, uncultured walled bacteria two proteobacteria have been phylogenetically characterized; the citrus huanglongbing (greening) (Jagoueix et al. 1994) and the strawberry chlorosis bacterium (Zreik et al. 1998). Both have been phylogenetically characterized based on the polymorphism within the rDNA sequences. The L10/L12 intergenic rDNA sequences were used to cluster the 'Candidatus Liberibacter' species isolated in Kenya as compared to those posted in the genebank (Figure 1). The Kenyan strains of the 'Candidatus Liberibacter' species clustered within the alpha $(\alpha)$ subdivision of proteobacteria. The Kenyan strains clustered away from the other African strains but with low bootstrap values of 19 (Figure 1), showing that the difference between the African strains is not wide. The Kenyan strains formed a cluster with the South African isolates 'Capensis' (Garnier et al. 2000) and 'Nelspruit' (Planet et al. 1995) with bootstrap values of 76 (Figure 1). This showed that the Kenyan strains are more closely related to the South African strains than the Asian strains. However the Asian isolates ('Thai', 'India', 'China', 
'Japan', 'Florida', 'Asia' (Villechanoux et al. 1993), and 'Pakistan' (Chohan et al. 2007) clustered within the $\alpha$ subdivision. Other members of the $\alpha$ subdivision including; Agrobacterium tumefaciens str. C58 (Wood et al. 2001), Rickettsia rickettsii str. 'Sheila Smith', Brucella abortus (Campos et al. 1998), and Bartonella tribocorum CIP105476 (Saenz et al. 2007), clustered with all $\alpha$-2 proteobacteria away from Escherichia coli O157.H7 str. Sakai (Makino et al. 1999; Yokoyama et al. 2000; Hayashi et al. 2001) that represented the gamma $(\gamma)$ subdivision of proteobacteria.

Ribosomal protein sequences have been utilized for phylogenetic analysis in eubacteria, due to their evolutionary important structural and functional properties and the existence of conserved domains (Müller and Wittmann-Liebold, 1997). The nusG-rplKAJL-rpoBC gene cluster has been previously used to study phylogenetic relationships in Liberibacters (Villechanoux et al. 1993). The L10 amino acid sequence phylogeny shows the Kenyan isolates (UM3, UM4, LM5, LM4, LM3, and LH4) clustering with other $\alpha$ proteobacteria. The Kenyan strains and the South African strain 'Nelspruit' (Planet et al. 1995), form a distinct cluster with high bootsrap values away from the South African isolate 'Capensis' (Garnier et al. 2000) (Figure 2). However, the Kenyan and the South African isolates share a common origin more recent than the one they share with the Asian isolates ('Thai', 'Japan', 'India', 'Asia', 'China' and 'Florida') denoting the close relationship between the Kenyan and South African isolates (Figure 2). Other members of the $\alpha$ subdivision of Proteobacteria Agrobacterium tumefaciens str. C58 (Goodner et al. 2001; Wood et al. 2001), Rhizobium leguminosarum bv. viciae 3841 (Young et al. 2006), Bartonella henselae str. Houston-1 (Alsmark et al. 2004), Brucella abortus biovar 1 str. 9-941 (Halling et al. 2005), Ochrobactrum anthropi ATCC 49188. Escherichia coli O157.H7 str. Sakai (Yokoyama et al. 2000; Hayashi et al. 2001), diverged from the Liberibacters earlier and forms a cluster with a bootstrap value of 93 .

The L10/L12 rDNA and the L10 protein phylogenetic clusters show that the Kenyan isolates and other Liberibacters are members of the $\alpha$ subdivision of proteobacteria. This is consistent with findings using the omp gene (Bastianel et al. 2005), the 16S rRNA (Jagoueix et al. 1994, Teixeira et al. 2005b), the 16S rDNA (Garnier et al. 2000) and the 16S/23S rDNA (Jagoueix et al. 1997). Therefore, the L10/L12 intergenic rDNA and the L10 protein serves as a good tool for phylogeny analysis among 'Candidatus Liberibacter' species, however, the region cannot be used to cluster within a species as was reported for the 16S rDNA and 16/23S rDNA. (Jagoueix et al. 1997; Teixeira et al. 2005b). These results suggest that, the 'Candidatus Liberibacters' active in the country maybe South African in origin.

\section{CONCLUDING REMARKS}

The isolated HLB causing proteobacteria in Kenya was more closely related to the 'Candidatus L. africanus' strains from South Africa than the 'Candidatus L. asiaticus' strains isolates from Asia with respect to the L10 and L12 rDNA and amino acid sequences and the L10/L12 intergenic DNA sequences. There was high homology in L10 and L12 rDNA and amino acid sequences and the L10/L12 intergenic DNA sequences of alpha proteobacteria isolated from different agro-ecological zones in Kenya. Phylogeny analysis on the L10/L12 rDNA and the L10 amino acid sequence shows significant clusters within the 'Candidatus Liberibacter' species with the Kenyan strains being closely related to the South African strains. The HLB disease causing bacteria in Kenya is distinct from the South African but they have a common origin more recent than the one they share with the Asian HLB causing bacteria.

\section{REFERENCES}

ALSMARK, Cecilia M.; FRANK, Caroline A.; KARLBERG, Olof E.; LEGAULT, Boris-Antoine; ARDELL, David H.; CANBÄCK Björn; ERIKSSON, AnnSofie; NASLUND, Kristina A.; HANDLEY, Scott A.; HUVET, Maxime; LASCOLA, Bernard; HOLMBER, Martin G. and ANDERSSON, Siv G. The louse-borne human pathogen Bartonella quintana is a genomic derivative of the zoonotic agent Bartonella henselae. Proceedings of the National Academy of Sciences of the United States of America, June 2004, vol. 101, no. 26, p. 9716-9721.

ALTSCHUL, Stephen F.; MADDEN, Thomas L.; SCHÄFFER, Alejandro A.; ZHANG, Jinghui; ZHANG, Zheng; MILLER, Webb and LIPMAN, David J. Gapped BLAST and PSI-BLAST: a new generation of protein database search programs. Nucleic Acids Research, September 1997, vol. 25, no. 17, p. 3389-3402.

APPLIED BIOSYSTEMS BigDye ${ }^{\circledR}$ Terminator v3.1 Cycle sequencing kit protocol. 2002. Available from Internet: http://www.appliedbiosystems.com.

BAN, Nenad; NISSEN, Poul; HANSEN, Jeffrey; CAPEL, Malcom; MOORE, Peter B. and STEITZ, Thomas A. Placement of protein and RNA structures into a $5 \AA$ resolution map of the $50 \mathrm{~S}$ ribosomal subunit. Nature, August 1999, vol. 400, no. 6747, p. 841-847.

BAN, Nenad; NISSEN, Poul; HANSEN, Jeffrey; MOORE, Peter B. and STEITZ, Thomas A. The complete atomic structure of the large ribosomal subunit at $2.4 \AA$ resolution. Science, August 2000, vol. 289, no. 5481, p. 905-920.

BASTIANEL， C.; GARNIER-SEMANCIK, M.; RENAUDIN, J.; BOVÉ, J.M. and EVEILLARD, S. Diversity of 'Candidatus Liberibacter asiaticus' based on omp gene sequence. Applied and Environmental 
Microbiology, November 2005, vol. 71 no. 11, p. 64736478.

BEAUCLERK, A.A.D.; CUNDLIFFE, E. and DIJK, J. The binding site for ribosomal protein complex L8 within 23S ribosomal RNA of Escherichia coli. Journal of Biological Chemistry, May 1984, vol. 259, no. 10, p. 6559-6563.

BOVÉ, J.M.; CALAVAN, E.C.; CAPOOR, S.P.; CORTEZ, R.E. and SCHWARZ, R.E. Influence of temperature on symptoms of California stubborn, South African greening, Indian citrus decline and Philippines leaf mottling diseases. In: Proceedings of the $6^{\text {th }}$ Conference of the International Organisation of Citrus virologists. Riverside, 1974, p. 1215.

BOVÉ, Joseph M. Huanglongbing: a destructive, newlyemerging, century-old disease of citrus. Journal of Plant Pathology, March 2006, vol. 88, no. 1, p. 7-37.

BOYKIN, Laura M.; BAGNALL, Ruth; FROHLICH, Don R.; HALL, David G.; HUNTER, Wayne B.; KATSAR, Catherine S.; McKENZIE, Cindy L.; ROSELL, Rosemarie C. and SHATTERS, Robert G. Twelve polymorphic microsatellite loci from the Asian Citrus Psyllid, Diaphorina citri (Kuwayama), the vector for citrus greening disease (Huanglongbing). Molecular Ecology Notes, November 2007, vol. 7, no. 6, p. 1202-1204.

CAMPOS, Eleonora; CRAVERO, Silvio L.; BOSCHIROLI, Maria L.; ARESE, Alicia I. and ROSSETTI, Osvaldo L. Genetic organization of the rplJLrpoB operon in Brucella abortus. In: Networking in Brucellosis research II. Proceedings of the UNU/Biolac Brucellosis workshop. United Nations University Press, Tokio, 1998, p. 1-8.

CHOHAN, Shahid N.; QAMAR, Raheel; SADIQ, Ifran; AZAM, Maleeha; HOLFORD, Paul and BEATTIE, Andrew. Molecular evidence for the presence of Huanglongbing in Pakistan. Australasian Plant Disease Notes, March 2007, vol. 2, no. 1, p. 37-38.

COLETTA-FILHO, H.D.; TAKITA, M.A.; TARGON, M.L.P.N. and MACHADO, M. Analysis of 16S rDNA Sequences from citrus huanglongbing bacteria reveal a different $\mathrm{Ca}$. 'Liberibacter' strain associated with citrus disease in São Paulo. Plant Disease, August 2005, vol. 89, p. 848-852.

DECKERT, Gerard; WARREN, Patrick V.; GAASTERLAND, Terry; YOUNG, William G.; LENOX, Anna L.; GRAHAM, David E.; OVERBEEK, Ross; SNEAD, Marjory A.; KELLER, Martin; AUJAY, Monette; HUBER, Robert; FELDMAN, Robert A.; SHORT, Jay M.; OLSEN, Gary J. and SWANSON, Ronald V. The complete genome of the hyperthermophilic bacterium Aquifex aeolicus. Nature, March 1998, vol. 392, no. 6674, p. 353358.
FANG, Ding; JUN, Yi G. and PING, Wang G. Research on the PCR and nested-PCR detection of citrus Huanglongbing pathogen. Acta Horticulturae Sinica, December 2004, vol. 31, no. 6, p. 803-806.

FRENCH, J.C.; KAHLKE, C.J. and DA GRACA, J.V. First record of the Asian citrus psylla Diaphorina citri Kuwayama (Homoptera: Psyllidae) in Texas. Subtropical Plant Science, January 2001, vol. 53, p. 14-14.

FUSAYASU, Satoshi; SATO, Tetsuji and SHIMIZU, Hiroaki. Detection of citrus greening disease (Candidatus liberobacter asiasticum) by loop-mediated isothermal amplification. Research Bulletin of the Plant Protection Service Japan, 2006, vol. 1, no. 42, p. 81-87.

GARNIER, Monique; MARTIN-GROS, Gilles and BOVÉ, Joseph M. Monoclonal antibodies against the Bacterial-like Organism Associated with Citrus Greening Disease. Annales de Microbiologie (Annales de l'Institut Pasteur), 1987, vol. 138, p. 639-690.

GARNIER, Monique and BOVÉ, Joseph M. Citrus greening disease and the greening bacterium. In: Proceedings of the $12^{\text {th }}$ Conference of the International Organisation of Citrus virologists. Department of Plant Pathology, University of California, Riverside. MORENO, P.; DA GRAÇA, J.V. and TIMMER, L.W. eds. 1993, p. 212-219.

GARNIER, Monique; JAGOUEIX-EVEILLARD, Sandrine; CRONJE, Pieter R.; LE ROUX, Hennie F. and BOVÉ, Joseph M. Genomic characterization of a Liberibacter present in an ornamental rutaceous tree, Calodendrum capense, in the Western Cape Province of South Africa. Proposal of 'Candidatus Liberibacter africanus subspecies capensis'. International Journal of Systematic Evolutionary Microbiology, November 2000, vol. 50, no. 6, p. 2119-2125.

GOODNER, Brad; HINKLE, Gregory; GATTUNG, Stacie; MILLER, Nancy; BLANCHARD, Mary; QUROLLO, Barbara; GOLDMAN, Barry S.; CAO, Yongwei; ASKENAZI, Manor; HALLING, Conrad; MULLIN, Lori; HOUMIEL, Kathryn; GORDON, Jeffrey; VAUDIN, Mark; IARTCHOUK, Oleg; EPP, Andrew; LIU, Fang; WOLLAM, Clifford; ALLINGER, Mike; DOUGHTY, Dahlia; SCOTT, Charlaine; LAPPAS, Courtney; MARKELZ, Brian; FLANAGAN, Casey; CROWELL, Chris; GURSON, Jordan; LOMO, Caroline; SEAR, Carolyn; STRUB, Graham; CIELO, Chris and SLATER, Steven. Genome sequence of the plant pathogen and biotechnology agent Agrobacterium tumefaciens C58. Science, December 2001, vol. 294, no. 5550, p. 2323-2328.

GRAFTON-CARDWELL, Elizabeth E.; GODFREY, Kris E.; ROGERS, Michael E.; CHILDERS, Carl C. and STANSLY, Philip A. Asian citrus psyllid [online]. University of California, Division of Agricultural and 
Natural Resources. 2007, p. 1-9 [cited March 2009]. Available from Internet: http://ucanr.org/freepubs/docs/8205.pdf. Publication 8205.

HALLING, Shirley M.; PETERSON-BURCH, Brooke D.; BRICKER, Betsy J.; ZUERNER, Richard L.; QING, Zhang.; LI, Ling-Ling; KAPUR, Vivek; ALT, David P. and OLSEN, Steven C. Completion of the genome sequence of Brucella abortus and comparison to the highly similar genomes of Brucella melitensis and Brucella suis. Journal of Bacteriology, April 2005, vol. 187, no. 8, p. 2715-2726.

HAYASHI, Tetsuya; MAKINO, Kozo; OHNISHI, Makoto; KUROKAWA, Ken; ISHII, Kazuo; YOKOYAMA, Katsushi; HAN, Chang-Gyun; OHTSUBO, Eiichi; NAKAYAMA, Keisuke; MURATA, Takahiro; TANAKA, Masashi; TOBE, Toru; IIDA, Tetsuya; TAKAMI, Hideto; HONDA, Takeshi; SASAKAWA, Chihiro; OGASAWARA, Naotake; YASUNAGA, Teruo; KUHARA, Satoru; SHIBA, Tadayoshi; HATTORI, Masahira and SHINAGAWA, Hideo. Complete genome sequence of enterohemorrhagic Escherichia coli O157:H7 and genomic comparison with a laboratory strain K-12. DNA Research, February 2001, vol. 8, no. 1, p. 11-22.

HOCQUELLET, Agnes; BOVÉ, Joseph M. and GARNIER, Monique. Production and evaluation of nonradioactive probe for the detection of the two 'Candidatus Liberobacter' species associated with the citrus huanglongbing (greening). Molecular and Cellular Probes, December 1997, vol. 11, no. 6, p. 433-438.

HOCQUELLET, Agnes; BOVÉ, Joseph M. and GARNIER, Monique. Isolation of DNA from the uncultured 'Candidatus Liberobacter' Species Associated with citrus Huanglongbing by RAPD. Current Microbiology, March 1999a, vol. 38, no. 3, p. 176-182.

HOCQUELLET, Agnes; TOORAWA, P.; BOVÉ, Joseph $\mathrm{M}$. and GARNIER, Monique. Detection and identification of two 'Candidatus Liberobacter' species associated with the citrus huanglongbing by PCR amplification of the ribosomal protein genes of the Beta operon. Molecular and Cellular Probes, October 1999b, vol. 13, no. 5 p. 373-379.

HUGENHOLTZ, Philip. Exploring prokaryotic diversity in the genomic era. Genome Biology, January 2002, vol. 3, no. 2, p. 1-8.

HUNG, T.H.; HUNG, S.-C.; CHEN, C.-N.; HSU, M.-H. and SU, H.-J. Detection by PCR of Candidatus Liberibacter asiaticus, the bacterium causing citrus huanglongbing in vector psyllids: application to the study of vector-pathogen relationships. Plant Pathology, February 2004, vol. 53, no 1, p. 96-102.

JAGOUEIX, Sandrine; BOVÉ, Joseph M. and GARNIER, Monique. The phloem-limited bacterium of greening disease of citrus is a member of the $\alpha$ subdivision of the proteobacteria. International Journal of Systematic and
Evolutionary Microbiology, July 1994, vol. 44, no. 3, p. 379-386.

JAGOUEIX, Sandrine; BOVÉ, Joseph M. and GARNIER, Monique. PCR detection of the two 'Candidatus Liberibacter' species associated with greening disease in citrus. Molecular and Cellular Probes, February 1996, vol. 10, no. 1, p. 43-50.

JAGOUEIX, Sandrine; BOVÉ, Joseph M. and GARNIER, Monique. Comparison of the 16S/23S Ribosomal Intergenic Regions of 'Candidatus Liberibacter asiaticus' and 'Candidatus Liberibacter africanus', the two species associated with Citrus Huanglongbing (Greening) Disease. International Journal of Systematic Bacteriology, January 1997, vol. 20, no. 1, p. 224-227.

KLENT, Hans-Peter; MEIER, Thomas-Dirk; DUROVIC, Peter; SCHWASS, Volker; LOTTSPEICH, Friedrich; DENNIS, Patrick P. and ZILLIG, Wolfram. RNA polymerase of Aquifex pyrophilus: implications for the evolution of the bacterial operon rpoBC operon and extremely thermophilic bacteria. Journal of Molecular Evolution, May 1999, vol. 48, no. 5, p. 528-541.

LAN, Liao X.; FANG, Zhu S.; JUN, Zhao W.; KUAN, Luo; XIANG, Qi Y.; YUN, Chen H.; KUN, He and XIANG, Zhu $\mathrm{X}$. Cloning and sequencing of citrus Huanglongbing pathogen 16S rDNA and its detection by real-time fluorescent PCR. Journal of Agricultural Biotechnology, January 2004, vol. 12, no. 1, p. 80-85.

LI, Wenbin; HARTUNG, John S. and LEVY, Laurene. Evaluation of DNA amplification methods for improved detection of 'Candidatus Liberibacter Species' associated with citrus Huanglongbing. Plant Disease, January 2007, vol. 91, no. 1, p. 51-58.

LI, Wenbin; LI, Dayan; TWIEG, Elizabeth; HARTUNG, John S. and LEVY, Laurene. Optimized quantification of unculturable Candidatus Liberibacter spp. in host plants using real-time PCR. Plant Disease, June 2008, vol. 92, no. 6, p. 854-861.

LILJAS, Anders and GUDKOV, Anatoly T. The structure and dynamics of ribosomal protein L12. Biochimie, October 1987, vol. 69, no. 10, p. 1043-1047.

MAKINO, Kozo; YOKOYAMA, Katsushi; KUBOTA, Yoshino; YUTSUDO, Chikako H.; KIMURA, Sigenobu; KUROKAWA, Ken; ISHII, Kazuo; HATTORI, Masahiro; TATSUNO, Ichiro; ABE, Hiroyuki; IIDA, Tetsuya; YAMAMOTO, Koichiro; OHNISHI, Makoto; HAYASHI, Tetsuya; YASUNAGA, Teruo; HONDA, Takeshi; SASAKAWA, Chihiro and SHINAGAWA, Hideo. Complete nucleotide sequence of the prophage VT2-Sakai carrying the verotoxin 2 genes of the enterohemorrhagic Escherichia coli O157:H7 derived from the Sakai outbreak. Genes Genetic Systems, October 1999, vol. 74, no. 5, p. 227-239. 
MÜLLER, E.C. and WITTMANN-LIEBOLD, B. Phylogenetic relationship of organisms obtained by ribosomal protein comparison. Cellular and Molecular Life Sciences, January 1997, vol. 53, no. 1, p. 34-50.

MURRAY, R.G.E. and SCHLEIFER, K.H. Taxonomic notes: a proposal for recording the properties of putative taxa of prokaryotes. International Journal of Systematic and Evolutionary Microbiology, January 1994, vol. 44, no. 1, p. 174-176.

NEI, Masatoshi and KUMAR, Sudhir. Molecular Evolution and Phylogenetics. New York; Oxford University Press, 2000, 333 p. ISBN 0195135849.

OKUDA, Mitsuru; MATSUMOTO, Mitsuhito; TANAKA, Yuko; SUBANDIYAH, Siti and IWANAMI, Toru. Characterization of the tufB-secE-nusG-rplKAJL-rpoB gene cluster of the citrus greening organism and detection by loop-mediated isothermal amplification. Plant Disease, July 2005, vol. 89, no. 7, p. 705-711.

OLIVEIRA, Sergio C.; ZHU, Yingxun and SPLITTER, Gary. Sequences of the rplJL operon containing the L10 and L7/L12 genes from the Brucella abortus. Gene, March 1994, vol. 140, no. 1, p. 137-138.

PERKIN-ELMER CORPORATION, ABI Prism Big Dye Terminator Cycle Sequencing Ready Reaction Mix Protocol (p/n 4303237 Rev. A). 1997.

PETTERSON, Ingvar. Studies on the RNA and protein binding sites of the E. coli ribosomal protein L10. Nucleic Acids Research, June 1979, vol. 6, no. 7, p. 2637-2646.

PETTERSON, I.; HARDY, S.J. and LILJAS, A. The ribosomal protein L8 is a complex L7/L12 and L10. Federation of European Science Letters, 1976, vol. 64, no. 1, p. 135-138.

PLANET, Pascale; JAGOUEIX, Sandrine; BOVÉ, Joseph M. and GARNIER, Monique. Detection of the African citrus greening Liberobacter by amplification, cloning and sequencing of the rplKAJL-rpoBC operon. Current Microbiology, March 1995, vol. 30, no. 3, p. 137-141.

Qiagen Guide. Template Purification and DNA Sequencing. 2 ${ }^{\text {nd }} E d$. QIAGEN. 1998.

SAENZ, Henri L.; ENGEL, Philipp; STOECKLI, Michèle C.; LANZ, Christa; RADDATZ, Günter; VAYSSIERTAUSSAT, Muriel; BIRTLES, Richard; SCHUSTER, Stephan C. and DEHIO, Christoph. Genomic analysis of Bartonella identifies type IV secretion systems as host adaptability factors. Nature Genetics, December 2007, vol. 39, no. 12, p. 1469-1476.

SUBANDIYAH, Siti; IWANAMI, Toru; TSUYUMU, Shinji and IEKI, Hiroyuki. Comparison of 16S rDNA and $16 S / 23 S$ intergenic region sequences among citrus greening organisms in asia. Plant Disease, January 2000, vol. 84, no. 1, p.15-18.

TAMURA, Koichiro; NEI, Masatoshi and KUMAR, Sudhir. Prospects for inferring very large phylogenies by using the neighbor-joining method. Proceedings of the National Academy of Sciences of the United States of America, July 2004, vol. 101, no. 30, p. 11030-11035.

TAMURA, Koichiro; DUDLEY, Joel; NEI, Masatoshi and KUMAR, Sudhir. MEGA4: Molecular Evolutionary Genetics Analysis (MEGA) software version 4.0. Molecular Biology and Evolution, May 2007, vol. 24, no. 8, p. 1596-1599.

TATINENI, Satyanarayana; SAGARAM, Uma Shankar; GOWDA, Siddarame; ROBERTSON, Cecile J.; DAWSON, William O.; IWANAMI, Toru and WANG, Nian. In planta distribution of 'Candidatus Liberibacter asiaticus' as revealed by polymerase chain reaction (PCR) and real-time PCR. Phytopathology, May 2008, vol. 98, no. 5, p. 592-599.

TEIXEIRA, Diva do Carmo; AYRES, Antonio J.; DANET Jean L.; JAGOUEIX-EVEILLARD, Sandrine; SAILLARD, Coletteand and BOVÉ, Joseph M. First report of a Huanglongbing-like disease of citrus in São Paulo State, Brazil and association of a new Liberibacter species, 'Candidatus Liberibacter americanus', with the disease. Plant Disease, January 2005a, vol. 89, p. 107.

TEIXEIRA, D.C.; DANET, J.L.; EVEILLARD, S.; MARTINS, E.C.; JUNIOR, W.C.J.; YAMAMOTO, P.T.; LOPES, S.A.; BASSANEZI, R.B.; AYRES, A.J.; SAILLARD, C. and BOVÉ, J.M. Citrus Huanglongbing in São Paulo State, Brazil: PCR detection of the "Candidatus" liberibacter species associated with the disease. Molecular Cellular Probes, June 2005b, vol. 19, no. 3, p. 173-179.

TEIXEIRA, Diva do Carmo; SAILLARD, Colette; JAGOUEIX-EVEILLARD, Sandrine; DANET, Jean L.; DA COSTA, Paulo I.; AYRES, Antonio J. and BOVÉ, Joseph M. 'Candidatus Liberibacter americanus', associated with citrus huanglongbing (greening disease) in São Paulo State, Brazil. International Journal of Systematic and Evolutionary Microbiology, September 2005c, vol. 55, no. 5, p. 1857-1862.

TEIXEIRA, D.C.; EVEILLARD, S.; SIRAND-PUGNET, P.; WULFF, A.; SAILLARD, C.; AYRES, A.J. and BOVE, J.M. The tufB-secE-nusG-rplKAJL-rpoB gene cluster of the liberibacters: sequence comparisons, phylogeny and speciation. International Journal of Systematic and Evolutionary Microbiology, June 2008, vol. 58, no. 6, p. 1414-1421.

URASAKI, Naoya; KAWANO, Shinji; MUKAI, Hiroyuki; UEMORI, Takashi; TAKEDA, Osamu and SANO, Teruo. Rapid and sensitive detection of "Candidatus Liberibacter asiaticus" by cycleave isothermal and chimeric primer- 
initiated amplification of nucleic acids. Journal of General Plant Pathology, May 2008, vol. 74, no. 2, p. 151-155.

URASAKI, Naoya; UEHARA, Tsukasa and KAWANO Shinji. Highly reliable polymerase chain reaction assay for citrus huanglongbing (citrus greening disease) using the sucrose synthase gene as an internal control. Japanese Journal of Phytopathology, 2007, vol. 73, no. 1, p. 25-28.

VILLECHANOUX, Sandrine; GARNIER, Monique; LAIGRET, Frédéric; RENAUDIN, Joël and BOVÉ, Joseph $\mathrm{M}$. The genome of non-cultured bacterial-like organism associated with the citrus greening disease contains the nusG-rplKAJL-rpoBC gene cluster and the gene for a bacteriophage type DNA polymerase. Current Microbiology, March 1993, vol. 26, no. 3, p.161-166.

VILLECHANOUX, Sandrine; GARNIER, Monique; RENAUDIN, Joël and BOVÉ, Joseph M. Detection of several strains of the bacterium-like organism of citrus greening disease by DNA probes, Current Microbiology, February 1992, vol. 24, no. 2, p. 89-95.

WOOD, Derek W.; SETUBAL, Joao C.; KAUL, Rajinder; MONKS, Dave E.; KITAJIMA, Joao P.; OKURA, Vagner K.; ZHOU, Yang; CHEN, Lishan; WOOD, Gwendolyn E.; ALMEIDA, Nalvo F. Jr.; WOO, Lisa; CHEN, Yuching; PAULSEN, Ian T.; EISEN, Jonathan A.; KARP, Peter D.; BOVEE, Donald Sr.; CHAPMAN, Peter; CLENDENNING, James; DEATHERAGE, Glenda; GILLET, Will; GRANT, Charles; KUTYAVIN, Tatyana; LEVY, Ruth; LI, Meng-Jin; MCCLELLAND, Erin; PALMIERI, Anthony; RAYMOND, Christopher; ROUSE, Gregory; SAENPHIMMACHAK, Channakhone; WU, Zaining; ROMERO, Pedro; GORDON, David; ZHANG, Shiping; YOO, Heayun; TAO, Yumin; BIDDLE, Phyllis; JUNG, Mark; KRESPAN, William; PERRY, Michael; GORDON-KAMM, Bill; LIAO, Li; KIM, Sun; HENDRICK, Carol; ZHAO, Zuo-Yu; DOLAN, Maureen; CHUMLEY, Forrest; TINGEY, Scott V.; TOMB, JeanFrancois; GORDON, Milton P.; OLSON, Maynard V. and NESTER, Eugene $W$. The genome of the natural genetic engineer Agrobacterium tumefaciens C58. Science, December 2001, vol. 294, no. 5550, p. 2317-2323.

YOKOYAMA, Katsushi; MAKINO, Kozo; KUBOTA, Yoshino; WATANABE, Motoji; KIMURA, Sigenobu; YUTSUDO, Chikako H.; KUROKAWA, Ken; ISHII, Kazuo; HATTORI, Masahira; ABE, H.; IIDA, Tetsuya; YAMAMOTO, K.; HAYASHI, Tetsuya; YASUNAGA, Teruo; HONDA, Takeshi; SASAKAWA, Chihiro and SHINAGAWA, Hideo. Complete nucleotide sequence of the prophage VT1-Sakai carrying the Shiga toxin 1 genes of the enterohemorrhagic Escherichia coli O157:H7 strain derived from the Sakai outbreak. Gene, November 2000, vol. 258, no. 1-2, p. 127-139.

YOUNG, Peter J.; CROSSMAN, Lisa C.; JOHNSTON, Andrew W.; THOMSON, Nicholas R.; GHAZOUI, Zara
F.; HULL, Katherine H.; WEXLER, Margaret; CURSON, Andrew R.; TODD, Jonathan D.; POOLE, Philip S.; MAUCHLINE, Tim H.; EAST, Alison K.; QUAIL, Michael A.; CHURCHER, Carol; ARROWSMITH, Claire; CHEREVACH, Inna; CHILLINGWORTH, Tracey; CLARKE, Kay; CRONIN, Ann; DAVIS, Paul; FRASER, Audrey; HANCE, Zahra; HAUSER, Heidi; JAGELS, Kay; MOULE, Sharon; MUNGALL, Karen; NORBERTCZAK, Halina; RABBINOWITSCH, Ester; SANDERS, Mandy; SIMMONDS, Mark; WHITEHEAD, Sally and PARKHILL, Julian. The genome of Rhizobium leguminosarum has recognizable core and accessory components. Genome Biology, April 2006, vol. 7, no. 4, p. R34.

ZREIK, Leyla; BOVÉ, Joseph M. and GARNIER, Monique. Phylogenetic characterization of the bacteriumlike organism associated with marginal chlorosis of strawberry and proposition of a Candidatus taxon for the organism, 'Candidatus Phlomobacter fragariae'. International Journal of Systematic and Evolutionary Microbiology, April 1998, vol. 48, no. 1, p. 257-261. 